\title{
On the Speed of Transition in Central Europe
}

\section{Citation}

Aghion, Philippe, and Olivier Jean Blanchard. 1994. On the speed of transition in Central Europe. NBER Macroeconomics Annual 9: 283-320.

\section{Published Version}

http://dx.doi.org/10.2307/3585093

\section{Permanent link}

http://nrs.harvard.edu/urn-3:HUL.InstRepos:4481322

\section{Terms of Use}

This article was downloaded from Harvard University's DASH repository, and is made available under the terms and conditions applicable to Other Posted Material, as set forth at http:// nrs.harvard.edu/urn-3:HUL.InstRepos:dash.current.terms-of-use\#LAA

\section{Share Your Story}

The Harvard community has made this article openly available.

Please share how this access benefits you. Submit a story.

Accessibility 


\title{
Philippe Aghion and Olivier Jean Blanchard
}

\author{
OXFORD UNIVERSITY AND EBRD, AND MIT AND NBER
}

\section{On the Speed of Transition in Central Europe}

\section{Introduction}

Transition in Central Europe is four years old. State firms that dominated the economy are struggling with market forces. A new private sector quickly emerged and has taken hold. Unemployment, which did not exist, is high and still increasing.

These changes are raising many fears and many questions, to which economists have not yet given answers. Will this process of transition accelerate or slow down? Will unemployment keep increasing? Can things go wrong and how?

Our purpose in this paper is to develop a framework to think about those questions, and to-gingerly-use it to have a first pass at the answers. The basic structure of the model we develop is standard, that of the transition from a low- to a high-productivity sector. But we pay attention to two aspects that strike us as especially important. The first is the interaction between unemployment and the decisions of both state and private firms. The second are the idiosyncracies that come from the central planning legacy, from the structure of control within state firms, to the lack of many market institutions, which limits private sector growth.

Our paper starts with a description of transition in Poland so far. We choose Poland because we know it best; but, because it started first, this

An early draft of this paper owed a lot to discussions with Stanislaw Gomulka, Richard Layard, and Mark Schaffer. We thank Krzysztof Rybinski for assistance. We also thank Roland Benabou, Andrew Berg, Fabrizio Coricelli, Peter Diamond, Stanley Fischer, John Flemming, Roman Frydman, Michael Gavin, Martin Hellwig, Michael Kremer, Marcus Miller, Thomas Piketty, Brian Pinto, Andrei Shleifer, and Jean Tirole for comments and suggestions. 
is also the country where one has the most evidence to look at. Our purpose is to point to those aspects of transition that seem to us to be central to modeling later. We then develop a model and use it to think about the determinants of the speed of transition and the level of unemployment. Having done so, we return, in a more speculative mode, to the role of policy and the future in Poland, as well as the causes of cross-Central European country variations.

\section{The Transition in Poland So Far}

Our purpose here is not to give a detailed historical account of events, but a few guideposts are nevertheless needed. ${ }^{1}$ Two dates are important. The first is January 1990, when economic transition started in earnest, with price liberalization and stabilization; the second is January 1991, which saw the collapse of trade between Central and Eastern European countries. The evolution of the basic aggregates since 1990 is given in Table 1 . The first two years were associated with large decreases in gross domestic product (GDP) and even larger decreases in industrial production ${ }^{2}$. Output stabilized in mid-1992, and preliminary estimates of GDP growth in 1993 are around 4\%. Employment declined initially more slowly than GDP but has kept declining despite the turn in output. As a result, unemployment has steadily risen and now stands around $16 \%$. It is still increasing, but at the small rate of about $0.1 \%$ a month.

To understand the process of transition however, one must look beyond the aggregate numbers. To this we now turn.

Table 1 BASIC AGGREGATES: POLAND 1989-1993

\begin{tabular}{lcclll}
\hline & 1989 & 1990 & 1991 & 1992 & 1993 \\
\hline GDP & 100 & 88.4 & 81.7 & 82.9 & 86.2 \\
Industrial production & 100 & 75.8 & 66.7 & 69.4 & 73.7 \\
Unemployment rate & & $6.3 \%$ & $11.8 \%$ & $13.6 \%$ & $15.7 \%$ \\
\hline
\end{tabular}

GDP and industrial production: year averages, $1989=100.1993$ GDP: estimate. 1993 industrial production: average for the first 11 months. Unemployment rate: end of year.

Sources: OECD, and Polish Central Statistical Office (GUS).

1. For an early account, see Lipton and Sachs (1990). For more recent ones, see Sachs (1993), Berg and Blanchard (1994), and references therein.

2. There is a consensus that, for reasons ranging from conceptual to scope of coverage, reported declines in GDP overestimate true declines. But the sign of the decline and its large magnitude are not in doubt. For further discussion, see Berg. (1993). 


\subsection{THE HARDENING BUDGET CONSTRAINT}

As reform started, there were fears that state firms, which had operated under soft budget constraints and were now exposed to large relative cost and demand shocks, would successfully resist attempts to harden their budget constraint. These fears proved unjustified. In Poland as well as in most other Central European countries-and in sharp contrast to Russia - the budget constraint facing state firms has steadily hardened.

Subsidies to state firms have steadily decreased, from $4.5 \%$ of GDP in 1989 to $1.1 \%$ of GDP in 1993. Subsidies are, however, only the overt part of a soft budget constraint. Tax arrears, interenterprise arrears, and bank loans are the covert parts. They have all been used by state firms, but with limited and decreasing success.

Interenterprise arrears quickly mounted in 1990 and 1991, leading in effect to forced lending by profit makers to loss makers. But firms became increasingly reluctant to be forced lenders and increasingly asked for payment on delivery. By the end of 1991, interenterprise arrears were decreasing, and they are no longer a financing option for loss-making firms. Tax arrears, in effect forced lending by the government to loss-making firms, also increased initially. By the end of 1991, tax arrears from state firms were equal to $12 \%$ of budget revenues, or $4 \%$ of GDP, and increasing. Signals by the government that it was going to be tougher on enforcement were successful, and tax arrears have declined since. They stand at only $8 \%$ of revenues at the end of 1993.

The main source of hidden subsidies, however, has been bank loans. Given that the banking system had traditionally been a conduit for government transfers to firms, and remained state-owned, many state firms were initially able to get loans to cover their losses. A current bank cleanup cum privatization program, applied to the major banks, has given us good estimates of the extent of bad loans. ${ }^{3}$ The proportion of bad loans appears to be around $40 \%$ of loans to state firms, or about $8 \%$ of GDP. Most were made in the first two years of transition. And most were made to a small proportion of firms. ${ }^{4}$ The current process of privatization of banks appears likely to eliminate this option entirely. ${ }^{5}$

3. The cleanup program, and the way in which it deals with both the stock of bad loans and the incentives not to make new ones, is interesting in its own right. A description of the banking system and of the program are given in DAI (1993).

4. For further discussion, see Gomulka (1993a).

5. As part of the process of cleaning up of the banks' balance sheets, firms that cannot repay their debt must be closed or restructured. While one can anticipate that a number of firms, which are politically sensitive, will be kept alive, they appear likely to be the exception rather than the rule. 


\subsection{THE RETRENCHMENT OF STATE FIRMS}

The sources of the output decline during the first two years were macroeconomic stabilization, price liberalization, and the collapse of trade within the Council for Mutual Economic Assistance (CMEA). Their relative roles, as well as the specific channels through which these shocks affected output, are still the subject of research and controversy. ${ }^{6}$ Identifying specific sources is, however, not essential to our purposes. What is important is how state firms have adjusted to this decline in output. $^{7}$

The adjustment of employment to output has been slow. Labor productivity in industry (a number that reflects mostly the behavior of state firms) stood in December 1991 at only 77\% of its December 1989 level. Increases in production and further decreases in employment since have led to an increase in productivity, but it still stood, in December 1993, at only $85 \%$ of its pre-reform level. Much of the initial adjustment was accomplished through attrition: $70 \%$ of the employment decline in 1990 was accounted for by early retirements. As time has passed, however, layoffs have become increasingly important, and they now account for more than half of separations in state firms. ${ }^{8}$

Profits have disappeared. The ratio of gross profits to sales in state firms, which was equal to $28 \%$ in 1989 , declined to $23 \%$ in $1990,7 \%$ in $1991,3 \%$ in 1992 , and $4 \%$ for the first 11 months of $1993 .{ }^{9}$ This decrease in profits reflects mostly a trimming of the positive tail of the profit distribution. The share of income going to firms showing a gross loss in total income has remained roughly constant, equal to $19.3 \%$ in 1991, $20.4 \%$ in 1992 , and $20.0 \%$ in 1993 . Two sectors are showing a much larger share, mining (65\%) and transport equipment (55\%). Not surprisingly, these are also the two sectors that account for a large share of bad loans.

There is little evidence of restructuring beyond the labor shedding needed to avoid losses. The need for major reorganization of firms, for more modern capital equipment, has been widely documented. ${ }^{10}$ Yet

6. See, e.g., Berg and Blanchard (1994) versus Calvo and Coricelli (1993).

7. What follows is based in part on Blanchard et al. (1993). Recent studies of the behavior of state firms include Estrin et al. (1993) and Pinto et al. (1993). See also Fan and Schaffer (1993). A survey of case studies from Poland and other countries is given in Carlin et al. (1994).

8. The survey by Pinto et al. (1993) gives assessments by managers of "excess employment" in their firms as of mid-1992. The mean is $12 \%$.

9. The surprisingly large profit rates in 1990-in view of the output decline-reflect mostly accounting profits, FIFO inventory valuation combined with high inflation. See Schaffer (1992).

10. See Lipton and Sachs (1990). The many sectoral studies since have confirmed this view. 
little is happening. The evidence must by nature be more impressionistic here, because the distinction between closing and restructuring is often less clear-cut than we make it sound. But the aggregate evidence on investment supports the evidence from case studies. Restructuring should be associated with high levels of investment. Investment in industry has decreased instead, although by less than industrial production. It stood in 1991 at $86.0 \%$ of its 1989 value and has remained roughly constant since. The ratio of investment to sales in state firms in industry was equal to $5.4 \%$ for the first 11 months of 1993; this compares, e.g., to a ratio of $7 \%$ for U.S. manufacturing firms.

These evolutions are explained by the fact that state firms are controlled by workers with uncertain stakes and horizons: While the state has remained the de jure owner of state firms, it has had neither the means nor the inclination to exercise its control rights. Instead, control has reverted to the workers. In Poland, a latent structure of workers' control, the "workers councils," had been put in place in 1981. As long as managers had the backing of the center, these councils did not play an important role. But, in the vacuum created by reform, these councils assumed more power, including the ability to hire and fire managers. At this point, workers' councils have an effective veto power in any major decision concerning a firm. ${ }^{11}$ This, together with limited access to outside finance, explains why adjustment of employment has been slow, why profits have been appropriated by workers in the form of wages, and why restructuring and investment have remained low.

\subsection{THE SLOW PROGRESS OF PRIVATIZATION}

The incentives and the constraints faced by state firms we have just described have not come as a great surprise. Indeed, it was for these reasons that rapid privatization was seen as essential to restructuring. However, this was based on the assumption that the state, as the owner of firms, could dispose of them as it wanted. This assumption has turned out to be wrong, and precisely for the reasons we just analyzed: Like every other decision involving state firms, privatization has required, de facto, workers' approval. This has largely determined both the-slow-speed as well as the shape of privatization.

11. This does not, however, imply that managers, which have specific expertise, and the control of the agenda, are powerless. The game between managers and workers, and its implications, is explored in Aghion et al. (1993). 
There is a bewildering array of methods of privatization in Poland. ${ }^{12}$ But two have dominated, in terms of numbers, "capital privatization" and "privatization through liquidation."

"Capital privatization" is the sale of the firm to outsiders through sales or auctions. Under this arrangement, workers get $20 \%$ of the shares at a discount but give up control of the firm. So far, only 100 out of 8,000 state firms have been sold in this way. These have typically been medium-size firms, with better than average prospects, where workers were therefore more willing to give up control in exchange for external finance and expertise. Twenty-three of these firms are now quoted in the Warsaw Stock Exchange. ${ }^{13}$ The evidence is that firms privatized through this channel have done well, although deep restructuring has taken place only in those firms with large foreign participation. ${ }^{14,15}$

"Privatization through liquidation" has been quantitatively the most important channel, and it had been used by 850 firms at the end of 1993. It allows workers and management to buy their firm, by paying $20 \%$ of the estimated value of the firm, and making lease payments-at attractive terms - for the remainder over a period of 5-10 years. The firms that have taken this route have typically been small to medium-size firms, with less than 200 employees. While this is the channel preferred by workers, the evidence is however that it has typically not led to restructuring. The reasons are not hard to find. Majority ownership by insiders has made the firms unable to raise equity finance, except by selling a large or majority stake. Lease payments to the state have led to high leverage, making it difficult for the firms to raise debt finance or obtain further bank loans.

Even if one adds to those two channels "asset sales," sales of the assets of insolvent firms, which account for another 1,010 firms at the end of 1993 , only a total of about 2,000 firms, or $25 \%$ of state firms, have been privatized so far.

\subsection{THE GROWTH OF THE PRIVATE SECTOR}

Table 2 shows the evolution of state and private employment since 1989. While total employment has decreased, private sector employ-

12. Frydman et al. (1993) give a detailed description of methods and results up to the end of 1992 for all central European countries.

13. The share price index increased by a factor of 12 during 1993 . This large increase appears to be in part a speculative bubble. At the end of 1993, the price earnings ratio stood at 35 and did not seem to reflect fundamentals.

14. A detailed analysis of a number of firms privatized through different channels is given in Dabrowski et al. (1993).

15. A program known as "mass privatization" (a misnomer given its current size), which was approved in the summer of 1993, may, if implemented on schedule, lead to further privatization of about $200-400$ firms over the next few years. 
Table 2 PRIVATE AND STATE EMPLOYMENT: 1989-1993

\begin{tabular}{lrrrrrrr}
\hline & \multicolumn{3}{c}{ All firms } & & \multicolumn{2}{c}{ Medium / large firms } \\
\cline { 2 - 4 } Employment & 1989 & 1992 & 1993 & & 1992 & 1993 \\
\hline Total & 13.5 & 11.4 & 11.4 & & \\
Private & 1.8 & 4.8 & 5.3 & & 2.6 & 2.7 \\
State & 11.7 & 6.6 & 6.1 & & 6.4 & 6.1 \\
\hline
\end{tabular}

Numbers in the first three columns are for the end of the year and cover all employment outside of agriculture. Numbers in the last two columns cover employment outside of agriculture in firms with more than five employees and are averages for the first six months of each year.

Source: GUS.

ment has grown rapidly; private sector employment, which stood at $13 \%$ of total employment pre-reform, stood at $46 \%$ at the end of 1993. When agricultural employment is included, the share of employment in the private sector actually now exceeds $60 \% .{ }^{16}$ But these numbers come with a number of caveats.

The first is that part of the shift reflects classification rather than true changes. Cooperatives, which at the beginning of reform accounted for 1.5 million employees, have been reclassified as part of the private sector. The second is that much of the increase in private employment has taken place in individual businesses. This is clear from the numbers in the last two columns of Table 2, which give state and private employment in firms with more than five employees in 1992 and 1993, and yield two conclusions. The share of private employment in medium and large firms is only 30\%. And the increase from 1992 to 1993 was only a small 0.1 million. These two points deserve elaboration.

The initial increase of the private sector reflected rapid small privatization, i.e., leasing of shops and stores by local authorities, as well as the increase in trade and services induced by price liberalization. In December 1989 , there were 150,000 stores in Poland. Estimates are that, one year later, there were 300,000 stores, of which only 40,000 were owned by the state. ${ }^{17}$ At the end of $1993,84 \%$ of employment in trade was in the private sector.

Evidence on the creation of medium-size private firms, firms that can replace or compete with existing state firms, is less favorable. Private employment in firms with more than five employees in industry stands at 1.1 million, or $34 \%$ of total employment. (This includes employment in privatized firms as well.) Their performance, at least as measured in

16. More detailed numbers, as well as a more optimistic assessment than the one given here, are given in Rostowski (1993).

17. Frydman et al. (1993). 
official statistics, is not strong. Their reported profit rate for the first nine months of 1993 was roughly equal to zero, but this may be dismissed as accounting designed to avoid paying profit taxes. Average wages in the private sector stood at $90 \%$ of those in the state sector. Investment as a ratio to employment was only marginally higher than for their counterpart state firms. Case studies document that, except for firms involved in joint ventures with foreign investors, new private firms typically finance themselves from accumulated savings and retained earnings.

This points to the importance of foreign direct investment. Official estimates are that cumulative foreign direct investment so far has been only $\$ 1.0$ billion, or about $2 \%$ of GDP. Very small during the first two years, the flow doubled in 1993 compared with 1992.

\subsection{THE INCREASE AND THE NATURE OF UNEMPLOYMENT}

As Table 2 shows, the increase in private-sector employment has not offset the decrease in state employment, and unemployment has steadily increased. Registered unemployment stands at 3.0 million, or $16.0 \%$ of the labor force. An alternative estimate of unemployment comes from the newly available labor force survey. In December 1993, when registered unemployment stood at 2.8 million, estimated unemployment from the survey stood at a somewhat lower 2.3 million. ${ }^{18}$

Gross flows, in and out of employment, are substantially larger than net flows. ${ }^{19}$ In 1992, a net decrease of $10 \%$ of state employment was accounted for by accessions equal to $20 \%$ and separations equal to $10 \%$ of state employment. These rates, while lower than those in Western countries, reflect the heterogeneity of shocks across state firms. And turnover was also substantial in the private sector. A net increase of employment of 0.1 million in existing private firms in 1992 was accounted for by accessions equal to $15 \%$ and separations equal to $14 \%$ of private employment. Roughly half of all gross flows were directly from employment to employment and half to or from unemployment or nonparticipation.

Gross flows are still small in relation to the pool of unemployed. As a result, the turnover rate in unemployment is very low. The monthly exit rate from unemployment in 1992 was $4 \%$. The monthly exit rate from unemployment to employment was $2.3 \%$; compare this with a rate of $25 \%$ in the United States. And, despite a shift from a policy of open-ended unemployment benefits to benefits expiring after a year, the proportion of long-term unemployment is steadily increasing. The

18. Gora (1994) guesses that this difference reflects the fact that registering for unemployment entitles one to health care benefits, leading people classified as out of the labor force in the survey to register at the unemployment office.

19. The numbers that follow are constructed in Blanchard et al. (1993). 
proportion of workers unemployed for more than one year stood in mid-1993 at 39\% of total unemployment, and the proportion of workers unemployed for more than two years stood at $14 \%$.

The distribution of unemployment across age, sex, and education is roughly similar to that of Western European countries with similar rates of unemployment. The rate of unemployment is higher among the young and the unskilled. However, the geographical distribution of unemployment is very uneven. Unemployment is much lower in large cities. The unemployment rate in Warsaw was equal to $7.7 \%$ in 1993 , roughly half the national average.

\subsection{THE FISCAL AND POLITICAL IMPLICATIONS OF UNEMPLOYMENT}

High unemployment in turn is shaping the process of transition. It has made fiscal balance much more difficult to achieve. And it has also eroded the support for reform.

(1) The transition has led to dramatic movements in both government revenues and spending. Table 3 gives the basic numbers. ${ }^{20}$ We choose 1988 as a reference year, because 1988 is more representative of the structure of revenues and spending prereform than 1989.

Some of the changes in spending and revenues are due to transition per se, rather than to high unemployment. For example, on the revenue side, the appropriation of rents by workers in state firms, which has led to the disappearance of profits in state firms, has led in turn to a decrease in profit taxes of $8 \%$ of GDP, more than offsetting the decline in subsidies. The emergence of the private sector has been no substitute, because private firms have typically reported little or no profit so far. It took two years to put in place a personal income tax, which now yields

Table 3 THE BUDGET: $1988-1993$

\begin{tabular}{lrrr}
\hline (\% of GDP) & 1988 & 1992 & 1993 \\
\hline Revenues & 35.6 & 27.2 & 29.1 \\
Indirect tax & 10.8 & 9.0 & 11.0 \\
Profit tax & 12.1 & 4.5 & 4.0 \\
Expenditures & 37.0 & 33.3 & 32.5 \\
Subsidies to firms & 6.0 & 1.4 & 1.1 \\
Capital expenditures & 4.2 & 1.6 & \\
\hline
\end{tabular}

Source: 1988 and 1992: Quarterly Economic Review, EBRD, April 1993. 1993: Budget forecasts as presented in the 1994 draft budget.

20. See Lipton and de Combrugghe (1994) for more details up to 1992. 
$6 \%$ of GDP. It took three years to put in place a value-added tax, which replaced the turnover tax in 1993.

But, in addition, lower activity and high unemployment have made budget balance much more difficult. Despite the tightening of unemployment benefits, expenditures on labor market policies-which are partly off budget-have steadily increased. They stood in 1992 at $2 \%$ of GDP. ${ }^{21}$ Early retirements have contributed to the very large increase in pensions. $^{22}$

These changes have forced the government to rely on a combination of new taxes, cuts in capital expenditures, and budget deficits. Despite a clear need for more infrastructure, capital expenditures have been cut and stood at only $1.6 \%$ of GDP in 1993 . The budget deficit, which peaked at $6 \%$ of GDP in 1992, is forecast to stand at $4.1 \%$ of GDP in 1994.

(2) High unemployment largely explains the results of the 1993 elections, which saw the defeat of the coalition that had introduced and implemented reform since 1989 . The elections were won by a coalition of two conservative (in the Eastern European sense) parties, parties with ties to previous communist organizations. So far, the policy that has been followed has not differed fundamentally from the policies pursued earlier. But there is no doubt that higher unemployment increases the political pressure to soften the budget constraint facing state firms, and that this will remain the case in the future.

\section{Toward a Formalization}

We see three major elements in the story we have just presented.

First, relative cost and demand changes, together with a hardened budget constraint, have forced state firms to substantially reduce employment. But the deeper process of reorganization, of upgrading of capital, the process of restructuring for short, has been slow, both because of internal incentives and external constraints.

Second, the same relative cost and demand changes have led to a rapid initial increase in private employment, mostly in small-scale trade and services. But further growth of the private sector is constrained by factors ranging from lack of expertise to limited access to external finance. 
Third, the net effect of these changes in employment so far has been an increase in unemployment, which affects in turn both the speed of restructuring and the rate of private sector growth.

This leads us to develop the following model.

The economy is composed of two sectors, the state sector with employment $E$ and the private sector with employment $N$. The labor force is normalized to one, so that $E+N+U=1$, where $U$ is unemployment, equivalently the unemployment rate. Before the transition, all workers work in the state sector, so that $E=1$ and $N=U=0$.

\subsection{THE STATE SECTOR}

(1) We capture the initial effects of changes in the demand and cost structure by assuming that, at the start of transition, $\left(1-E_{0}\right)$ workers become unproductive, and state employment drops to $E_{0}$. We assume the remaining workers to have constant average product, $x$. The low productivity of state firms is captured by assuming that $x$ is less than $y$, the average product of workers in the private sector, described later.

(2) We capture restructuring by assuming that state firms can either operate at $x$ indefinitely, or restructure/privatize, a decision that leads to an initial decrease in employment, and an increase in the average product of the remaining workers.

Think of each firm as employing initially one worker with product $x$. We assume that, if the firm restructures, it reduces employment to only $\lambda$ workers, $\lambda<1$, with each remaining worker producing $y, y>x$ units of output. Thus, after restructuring, the firm produces $\lambda y$ units of output, which can be greater or less than $x$.

Let $s$ be the speed of restructuring of state firms, so that

$d E / d t=-s$.

We start by taking $s$ as a variable under the control of the government. This allows us to focus on the dynamics of the economy given $s$. As we have argued, however, this speed is in fact largely endogenous, with the decisions left to state firms themselves. Thus, later on, we look at the decision process within state firms, and endogenize $s$.

(3) We see these assumptions as capturing the initial adjustment of employment and the trade-offs faced by workers in restructuring. But some of the formalization choices deserve comments.

The assumption that the average product takes only two values, 0 or $x$, makes the model unfit to discuss the role of subsidies or tariffs in preventing the initial decline, from 1 to $E_{0} \cdot{ }^{23}$ The assumption that the

23. These issues are taken up in Flemming (1993). 
average product is the same in all firms eliminates the heterogeneity present in the data and leads to what are too sharp differences in regimes later on. The assumption of instantaneous elimination of unproductive jobs is at clear variance with the facts and makes the model ill suited to describe the early dynamics of transition; but we believe it is not misleading if our goal is to think about those dynamics in the future.

We think that the assumption that state firms can, after the elimination of $\left(1-E_{0}\right)$ workers, remain in a holding pattern, is reasonable. But it is not innocuous. It implies that while delays in restructuring have an opportunity cost, firms can survive without it, and the economy can operate at a low level of productivity. If for example, we assumed instead that, absent restructuring, state employment steadily declined, the dynamics and some of the conclusions of our model would be very different. We shall return to this issue later.

Finally, we make no distinction between privatization and restructuring. But the evidence we gave earlier shows that the relation between restructuring and privatization is much less tight than we assume here. Privatization does not necessarily imply restructuring. But, restructuring, to the extent that it requires outside finance, requires privatization; this is what we want to capture here.

\subsection{THE NEW PRIVATE SECTOR}

(1) We capture the initial effects of changes in the cost and demand structure on trade and services by assuming that at the start of transition, there is a discrete increase in private employment from 0 to $N_{0}$.

Thereafter, private job creation (i.e., the increase in private-sector employment not due to privatization/restructuring of state firms) is given by

$H=a(y-z-w)$,

where $H$ is private job creation, $a$ is a parameter, $y$ is the constant average product of labor in the private sector, $w$ is the wage in the private sector, and $z$ are taxes per worker. Thus, private job creation depends on profit per worker, the difference between the average product of labor, $y$, and direct and indirect labor costs, $(w+z)$.

(2) Private sector wages depend on labor market conditions, according to

$$
w=b+c(r+H / U)
$$


where $b$ is unemployment benefits, $r$ is the interest rate, $H / U$ is the ratio of hires to unemployment, and $c$ is a constant.

Equation (3) captures two basic notions. The first is simply that the private wage depends on labor market conditions. The second is that the correct indicator of labor market conditions is not the level of unemployment per se but rather the exit rate out of unemployment.

The equation is easily derived from efficiency wage considerations, and it is useful for later to derive it explicitly.

Assume that all hires are from unemployment, and there is no turnover in either the private or the state sector. This implies that total hires in the economy are equal to $H$, so that $H / U$ is indeed the exit rate from unemployment.

Let $V_{U}$ and $V_{N}$ be the values of being unemployed and employed in the private sector, respectively. These two values thus follow "arbitrage" equations:

$$
\begin{aligned}
& r V_{U}=b+(H / U)\left(V_{N}-V_{U}\right)+d V_{U} / d t \\
& r V_{N}=w+d V_{N} / d t .
\end{aligned}
$$

When unemployed, a worker receives unemployment benefits $b$ and has probability $H / U$ of becoming employed. When employed, a worker faces, by assumption, no risk of becoming unemployed again and, thus, receives the private-sector wage forever after.

Efficiency wage considerations can be summarized by the condition that firms choose a wage such that the value of being employed exceeds the value of being unemployed by some amount, thus, such that $V_{N}-V_{U}=c, c \geq 0$. Under that assumption, which obviously implies that $d V_{N} / d t-d V_{U} / d t=0$, taking the difference between the two earlier equations gives Equation (3) above.

(3) Let us again briefly discuss some of our choices of formalization.

We see the assumption of an initial stock adjustment, from 0 to $N_{0}$, followed by a slower process of job creation, as capturing the change in the nature of the increase in private employment over time. Small-scale trade and services, which dominated at the beginning, required little capital and expertise. However, these factors are essential to sustained private-sector growth.

Our assumption that the change rather than the level of private new employment is a function of profit per worker captures, we believe, two of the main constraints on job creation. The first is limited access to external finance, which implies that investment in new capacity and, thus, job creation, is limited by earnings. The second is costs of 
adjustment, some physical and conventional, and some coming from such aspects as learning by doing, accumulation of information, development of reputation in goods and financial markets, and so on. ${ }^{24}$ If the relation comes from costs of adjustment, however, it is likely to be forward looking: Before creating jobs, firms will worry about both current and future expected profits. We take this extension up later.

Some of the assumptions we make in the derivation of the wage equation are clearly counterfactual. There is, as we have shown, some turnover, and many hires are directly from state firms rather than from unemployment. ${ }^{25}$ But we do not think that these simplifications are misleading here. What is important is not the exact form of the wage equation but the existence of a relation between the exit rate from unemployment to employment, and the wage in the private sector.

Under the assumptions we have made so far, higher unemployment leads, through lower wages, to faster private job creation. But, as we have argued earlier, there are clearly also channels through which unemployment affects private job creation adversely. We now turn to those.

\subsection{TAXES AND UNEMPLOYMENT BENEFITS}

We formalize these adverse effects of unemployment, through the implications of unemployment, and unemployment benefits on the level of taxes. We assume that taxes are levied equally on employment, state and private, to finance unemployment benefits. This implies:

$U b=(1-U) z$

This relation has a straightforward implication. Higher unemployment, given unemployment benefits, leads to higher taxes per worker; thus, ceteris paribus, higher unemployment decreases private job creation. ${ }^{26}$

24. Chadha et al. (1992) develop a model of transition where the growth of the private sector is based explicitly on learning by doing. Atkeson and Kehoe [1992] focus on the role of information capital. A more explicit formalization of creation/destruction along the lines of Caballero and Hammour (1993) would be worth exploring. We shy away from it here.

25. Estimates in Blanchard et al. (1993) are that, in 1992, half of the flows into employment were directly from other employment.

26. An alternative interpretation of the same equation is that the transfers are private altruistic transfers from the employed to the unemployed, in the amount $b$ per unemployed. Our model of wage determination implies that such transfers will be reflected in higher wages in equilibrium, leading to exactly the total cost of labor to the firms as if they were collected in the form of taxes and distributed as unemployment benefits. 
This is the basic effect we want to capture. But the relation is a stand-in for many channels, which we described earlier. Among those are the following: (1) The decrease in employment has led not only to higher unemployment but also to early retirements, which also have to be financed. (2) While better infrastructure is essential to getting more foreign direct investment, the state has been forced to drastically reduce capital expenditures. (3) Unemployment has led private firms, and especially foreign investors, to worry about political uncertainty; the commitment of future governments to reform; and, thus, profit prospects in the future. An alternative formalization, which we shall sketch later when we extend the model to allow for job creation to depend on current and future expectations of profit, is that higher unemployment increases the probability that reform will "end." The results from this alternative specification are qualitatively similar to those we derive using Equation (6).

\subsection{TAKING CARE OF CORNERS}

In specifying our assumptions, it might have been more natural to specify the equations for state and private employment in terms of rates of change rather than changes, i.e., in terms of $(d E / d t) / E$ and $H / N$ than in terms of $d E / d t$ and $H$. We have chosen our specification because it substantially simplifies the analysis later, leaving only one state variable, unemployment, rather than two, employment-state or private-and unemployment. But, as a result of these assumptions, the economy can hit corners, and we have to state what happens when those are reached. Those conditions only play a role at the end of the transition or when things in the economy go very wrong, but they must be specified nevertheless:

First, state employment can only decline if it is positive in the first place, so that the condition (1) only holds for $E>0$ : for $E=0, d E / d t=$ 0 . Second, a similar condition must hold for private employment. Here, it is convenient and innocuous to make a slightly different assumption, that for $(y-z-w)<0, N=0$; i.e., private firms can close if they are losing money.

\section{Unemployment and the Speed of Restructuring}

In this and the next two sections, we take the model through its strides. Once this is done, we return to Poland and Central Europe.

Under our assumptions, unemployment follows:

$$
d U / d t=s(1-\lambda)-H \quad U_{0}=1-E_{0}-N_{0} .
$$


After the initial increase in unemployment, unemployment dynamics depend on the speed of restructuring and on private job creation. The flow into unemployment, $s(1-\lambda)$, depends on the speed of restructuring, and the proportion of workers losing their jobs in the process; the flow out of unemployment is equal to private job creation, $H$.

Private job creation in turn depends on unemployment through two channels, wages and taxes. Solving for the wage, using Equations (2), (3), and (6) gives

$$
(w-b)=[c a /(U+c a)][y+(r / a) U-((1 /(1-U)) b] .
$$

Replacing $w$ by its value from Equation (8), and $z$ by its value from Equation (6) gives private job creation as a function of unemployment:

$$
H=a[U /(U+c a)][y-r c-(1 /(1-U)) b] \equiv f(U) .
$$

The effect of unemployment through wages is captured in the first term in brackets: The higher is unemployment, the lower is the wage, and, thus, the higher is private job creation. The effect of unemployment through taxes is captured in the second term in brackets: The higher is unemployment, the higher are taxes, the lower is private job creation.

Figure 1 plots $H=f(U)$ as a function of $U$. When unemployment is equal to zero, the wage is equal to the average product $y$, preventing job creation. As unemployment increases, the effect that dominates initially is the direct effect on wages, so that private job creation

Figure 1 DYNAMICS OF UNEMPLOYMENT UNDER EXOGENOUS RESTRUCTURING

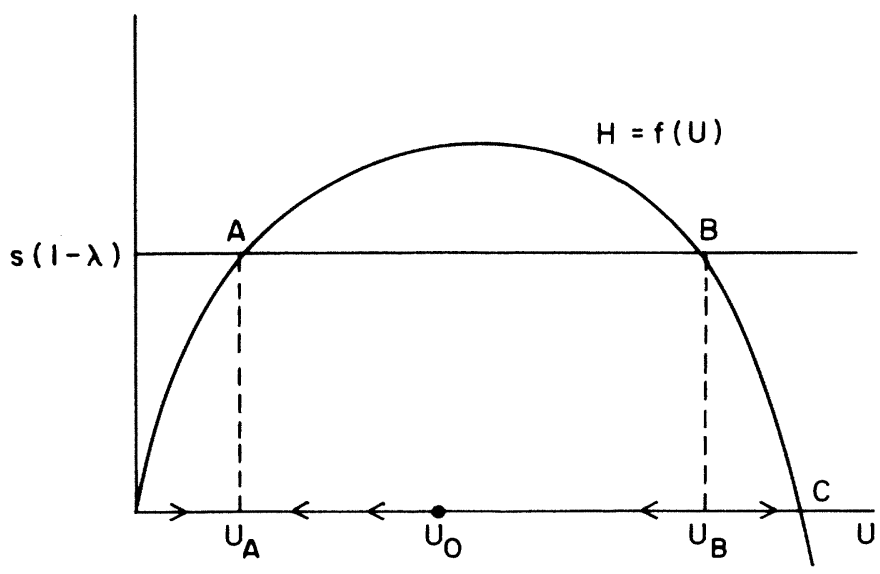


increases. As unemployment gets sufficiently large, however, the effect on taxes dominates the effect on wages, and private job creation declines. Indeed, as unemployment gets large enough, wages and contributions exceed the average product of labor, leading to the disappearance of the private sector altogether. Thus, at low unemployment, higher unemployment leads to more job creation; at high unemployment, higher unemployment leads to less job creation.

If we draw the flow into unemployment as a horizontal line at $s(1-\lambda)$ in Figure 1, we can use the figure to characterize the dynamics of unemployment. This yields two conclusions.

(1) There is a maximum speed of restructuring. If $s$ is such that $s(1-\lambda)$ exceeds the maximum rate of private job creation, then transition eventually fails. Starting from low unemployment, private job creation is initially positive and increasing. But it remains smaller than the flow into unemployment coming from restructuring, and unemployment becomes so large that the adverse fiscal effects become dominant. Private job creation declines, leading to a faster increase in unemployment. Eventually - at point $\mathrm{C}$ in the figure-the fiscal burden becomes so large that both the new and the privatized sectors become unprofitable and close down.

The details of the end process depend on the specific corner conditions, but the basic lesson is general. Too fast a rate of restructuring, even if the direct effect of restructuring is to increase output, i.e., even if $\lambda y>x$, can lead to too high a level of unemployment and derail the transition; this is because the indirect effects of restructuring through unemployment decrease private job creation and eventually lead to the collapse of the private sector.

(2) If the speed is less than this maximum, the case drawn in Figure 1, there are two equilibria, $U_{A}$ and $U_{B}$. The lower equilibrium is stable, the higher one unstable. If the initial net decrease in employment is so large that $U_{0}$ is to the right of $U_{B}$, then private job creation is insufficient to avoid a further increase in unemployment and, again, the eventual collapse of the private sector. But, as long as the initial level of unemployment, $U_{0}$, is less than $U_{B}$, the economy converges to the lower level of unemployment $U_{A}$.

At that unemployment rate, flows in and out of unemployment are equal. The private sector grows steadily from two sources, restructuring/privatization, $s \lambda$, and private job creation, $H$. Unemployment remains at $U_{A}$ until restructuring has been achieved, and the state sector has been fully transformed. An increase in the speed of restructuring leads to an increase in unemployment and to an increase in the rate of private job creation. 
This concludes our first pass at the dynamics. We now extend the model, first by looking more closely at private job creation, and then by looking more closely at the restructuring decision.

\section{A Forward-Looking Private Sector}

As we pointed out earlier, private job creation is likely to be, at least in part, forward looking. Even if current profits are high, many private firms, and especially foreign direct investors, will not invest if they expect conditions to deteriorate and profits to shrink in the future. But in turn, profits in the future may be low if private job creation is insufficient to avoid rising unemployment.

To explore this interaction, we modify our description of private job creation, Equation (2), to read

$H=\operatorname{arV}$

$r V=(y-z-w)+d V / d t$

where $V$ is the value of a new private job. Job creation now depends on the value of a new job. The value of a new job follows an arbitrage equation, which implies that it is the present value of profit, the difference between $y$ and direct and indirect costs, $(w+z){ }^{27}$

Under these assumptions, the dynamics reduce to two equations, in $U$ and $V$ :

$d U / d t=s(1-\lambda)-a r V$

$r V=f(U) / a+[U /(U+c a)] d V / d t$,

where $f(U)$ is defined as before (Equation 9).

The dynamics are characterized in Figure 2. The locus $(d U / d t=0)$ is a horizontal line in the $V-U$ space, at $V=s(1-\lambda) / a r$, such that private job creation is equal to the flow into unemployment from restructuring. The locus $(d V / d t=0)$ is given by $V=f(U) / a r$ and, thus, has the same properties as the $f(U)$ locus characterized in Figure 1.

27. This is where we can sketch the alternative formalization of the cost of unemployment in terms of its effect on the probability that reform ends. Let $p$ be the instantaneous probability that reform ends and that profits become, say, equal to zero. The equation giving the evolution of $V$ is then $(r+p) V=(y-z-w)+d V / d t$. Putting $b$ and $z$ both equal to zero so as to eliminate the effect of unemployment through taxation, and assuming instead that $p$ increases with unemployment, say that $p=U /(1-U)$, leads to conclusions similar to those presented in the text. 
Figure 2 DYNAMICS OF UNEMPLOYMENT WITH A FORWARD-LOOKING PRIVATE SECTOR

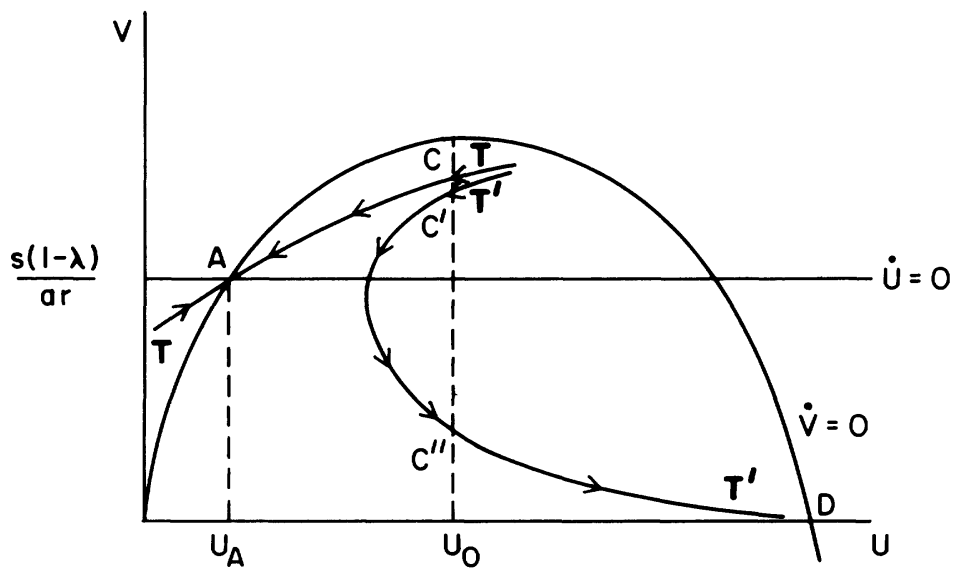

Figure 2 is drawn on the assumption that the two loci intersect, that the speed of restructuring is less than the maximum speed. We limit ourselves to this case here.

There are now (at least) two equilibrium paths. A complete description of the possible configurations goes beyond what we want to do here and would be of little interest. ${ }^{28}$ One possible configuration is given in Figure 2.

The first path is given by $T T$, the saddle point path associated with the lower unemployment equilibrium, $U_{A}$. Suppose that initial unemployment is equal to $U_{0}$. The economy starts at point $\mathrm{C}$ and converges over time to $\mathrm{A}$. Current profits are positive; together with anticipations of positive profits in the future, they lead to private job creation, and unemployment decreases to $U_{A}$. Transition proceeds from then on at constant unemployment $U_{A}$ until restructuring has been achieved.

But there is also a path where self-fulfilling pessimism leads to failure of the transition. This is the path $T^{\prime} T^{\prime}$, which goes to D instead. Starting from the same unemployment rate, $U_{0}$, there are two other possible evolutions, one starting at $C^{\prime}$, and one starting at $C^{\prime \prime}$, both on $T^{\prime} T^{\prime}$. Along the path starting from $C^{\prime}$, expectations of profit are sufficient to lead to enough job creation for a while. But eventually, unemployment

28. While $A$ is a saddle point, point $B$ can be either a sink or a node. This determines the dynamic properties of the model, in particular the number of paths from a given level of unemployment. 
increases, leading to the collapse of the private sector and the failure of transition. ${ }^{29}$ Along the path starting at $C^{\prime \prime}$, anticipations of future profit are even lower, and job creation is insufficient to prevent the increase in unemployment. Eventually again, the private sector collapses.

Multiple equilibria and self-fulfilling pessimism are not a theoretical novelty. But they capture the flavor of an important element of transition, in particular the interaction between foreign direct investment and unemployment. The fear of high unemployment and a political backlash has led to low foreign direct investment in some central European countries. But low foreign direct investment has led in turn to smaller private sector growth, higher unemployment, and a higher risk of political backlash.

The results also have policy implications. Within the logic of our model, there is no sense in which a lower speed, $s$, makes the good outcome more likely. But the government can announce a policy that eliminates the bad outcome. Announcing that restructuring will be suspended if unemployment crosses some threshold level of unemployment-any point between $U_{A}$ and $U_{B}$-achieves this result. Under such an announcement, the only perfect foresight path is $T T$, the good path.

Thus, in order to avoid self-fulfilling forecasts of the failure of transition, e.g., by foreign investors, the government may want to announce a flexible policy, i.e., announce that the rate of restructuring will slow down if unemployment gets too high. Flexibility in the speed of restructuring makes ultimate transition more credible.

Again, this result must come with a number of caveats.

First, our assumption that state firms can stay in a holding pattern is important here. It implies that the only cost of delayed restructuring is the opportunity cost of delayed higher productivity, and it poses no threat to the ultimate transition. If, absent restructuring, firms' employment decreased, there would potentially be risks from maintaining either too high or too low a speed of restructuring. ${ }^{30}$

Second, and closely related, flexibility in the speed of restructuring does not mean, in our model, increasing subsidies to state firms. But in practice, the line between the two is a thin one; more flexibility may be read by private firms as implying higher transfers, overt or covert, to state firms in the future, and thus lead to less private job creation.

Third, the government may have little choice than to be flexible anyway. If unemployment is high, workers in state firms are likely to 
strongly oppose any measure that puts them at risk of becoming unemployed. This takes us to our last extension, the endogenization of the speed of restructuring.

\section{Endogenous Restructuring}

As we showed earlier, the belief at the beginning of the reform process that governments could choose the speed of privatization and restructuring was wrong. Privatization has turned out to require workers' approval. What "workers' approval" means is ambiguous, however, and this raises a number of issues, which we take up first. ${ }^{31}$

\subsection{THE DECISION PROCESS WITHIN STATE FIRMS}

Let $V_{E}$ be the value for a worker of being employed in the unrestructured state sector. Let, as before, $V_{U}$ be the value of being unemployed. Assume, in line with our earlier assumption that restructuring comes with privatization, that wages in restructured/privatized firms are set in the same way as in the rest of the private sector. The value of being employed in the restructured firm is then the same as that of working in the new private sector, and we can use the same symbol for both, $V_{N}$.

Recall that restructuring implies that a proportion $\lambda$ of the workers will remain employed after restructuring, and a proportion $1-\lambda$ will become unemployed.

If all workers perceive an equal probability of keeping their job after restructuring, then-under the assumption of risk neutrality, an assumption that we have made implicitly until now in defining the various value functions as linear in wages and benefits-the condition for restructuring will be

$\lambda V_{N}+(1-\lambda) V_{u} \geq V_{E}$

For restructuring to occur, the expected value after restructuring must be greater than or equal to the value absent restructuring.

In most firms, the assumption that workers choose under a veil of ignorance is clearly wrong, however. In most cases, it is easy to identify parts of the firm that will surely have to close. What happens then depends on the decision process within the firm. If those workers who know they will lose their jobs can be fully compensated, through

31. These issues are closely related to how to buy off stakeholders in top-down privatization plans. See Boyko et al. (1993). 
severance pay, however, by those who are likely to keep theirs, then the condition will be the same as earlier.

Compensation of losers may be limited, and workers who are likely to lose their job as a result of restructuring will oppose restructuring. Under the extreme assumption of unanimity and no-transfers, the condition for restructuring becomes

$V_{U} \geq V_{E}$

Even those who lose their jobs must be no worse off as a result of restructuring. But this is not the only possible outcome. If decisions are closer to majority voting, and $\lambda$ is greater than one-half, then the decision is determined by those who know they will keep their jobs, and the condition becomes

$$
V_{N} \geq V_{E}
$$

Which condition applies has an important effect on both the speed of restructuring, and the nature of unemployment. Note that under condition (15), for example, the unemployed are no worse off than those in state firms, while they are under the other two conditions. The evidence on bargaining within state firms is not sufficiently well established for us to be very confident. ${ }^{32}$ We shall work with condition (14) and mention what would happen if one of the other conditions was used instead.

\subsection{THE TRANSITION UNDER ENDOGENOUS RESTRUCTURING}

Leaving aside details - to be given later-the transition under endogenous restructuring is as follows:

From its initial value, $U_{0}$, unemployment converges to an equilibrium value, $U^{*}$. This value is associated with an equilibrium speed of restructuring $s^{*}$. Restructuring then proceeds at that speed, generating a flow into unemployment equal to private job creation. This goes on until restructuring has been achieved, and all employment in the economy is private.

(1) It is easiest to start with a characterization of $U^{*}$ and $s^{*}$, the equilibrium unemployment, and speed of restructuring, and then describe the adjustment from $U_{0}$ to $U^{*}$.

32. Indeed, our discussion does not take into account the role and the bargaining of managers in firms. We further explore the decision process within state firms in Aghion et al. (1993). 
Along the transition path associated with $U^{*}$ and $s^{*}$, all variables that affect the values $V_{E}, V_{U}, V_{N}$ are constant (only the composition of employment is changing), so that $V_{E}, V_{U}, V_{N}$ are also constant. ${ }^{33}$

The value of being employed in a state firm absent restructuring is given by

$r V_{E}=w_{E}=x-z$

where $w_{E}$ is the wage in state firms. In the absence of owners, workers appropriate all rents, so that the wage is equal to $x$, the average product, minus $z$, taxes per worker.

From Equations (4) and (5), and the condition that $V_{N}=V_{U}+c$, the values of being unemployed and of being employed in the private sector, respectively, are given by

$r V_{N}=w$

$r V_{U}=w-r c$

When Equation (14) holds as an equality, using Equations (17) to (19) to eliminate $V_{E}, V_{N}$, and $V_{U}$ gives

$x-z=\lambda w+(1-\lambda)(w-c r)$.

As the wage depends on the level of unemployment, this implicitly characterizes equilibrium unemployment, $U^{*}$. Unemployment must be such that the wage in the state sector, the left-hand side of Equation (20), is equal to the probability of keeping the job after restructuring times the private wage, plus the probability of becoming unemployed times the flow utility of being unemployed.

To solve explicitly for $U^{*}$, note that, from Equation (2), the wage $w$ can be expressed as $y-z-f\left(U^{*}\right) / a$. Replacing the wage in Equation (20) and rearranging gives

$f\left(U^{*}\right)=a(y-x-(1-\lambda) c r)$.

This equation defines equilibrium unemployment, $U^{*}$.

33. We cheat here by using in effect a turnpike approximation. Those variables are constant until restructuring comes to an end; when restructuring comes to an end, however, the flow into unemployment stops, and unemployment decreases asymptotically to zero as a result of private job creation. This implies that the $V$ 's, which are forward looking, change before the end of restructuring. Far away enough from the end, however, these anticipation effects are small. Thus, we ignore them in order to be able to focus on a constant value of $U^{*}$. 
By using this relation, and the condition that flows in and out of unemployment are equal, the equilibrium speed of restructuring, $s^{*}$, is in turn given by

$$
(1-\lambda) s^{*}=a(y-x-(1-\lambda) c r) .
$$

(2) It is easy to derive, along the equilibrium path, the values of being employed in each of the two sectors and of being unemployed.

Equation (14), together with the efficiency wage condition that $V_{N}-V_{U}=c$, implies the following relation between $V_{N}, V_{E}$, and $V_{U}$ :

$$
V_{N}>V_{E}=V_{N}-(1-\lambda) c>V_{U}=V_{N}-c \text {. }
$$

Those employed in the private sector are better off than those employed in the state sector, who are in turn better off than the unemployed. The higher is the unemployment rate; the lower is each of these three values.

(3) Figure 3 characterizes equilibrium unemployment and speed. It plots both sides of Equation (21) against unemployment. Private job creation, $f(U)$, is, as before, first upward, then downward sloping. The right-hand side is a horizontal line, at $a(y-x-(1-\lambda) c r)$.

We have drawn Figure 3 so that the horizontal line intersects $f(U)$ twice. There are two other possible cases, which we briefly mention. The first arises when the right hand side of Equation (21) is negative. In

\section{Figure 3 DYNAMICS OF UNEMPLOYMENT UNDER ENDOGENOUS RESTRUCTURING}

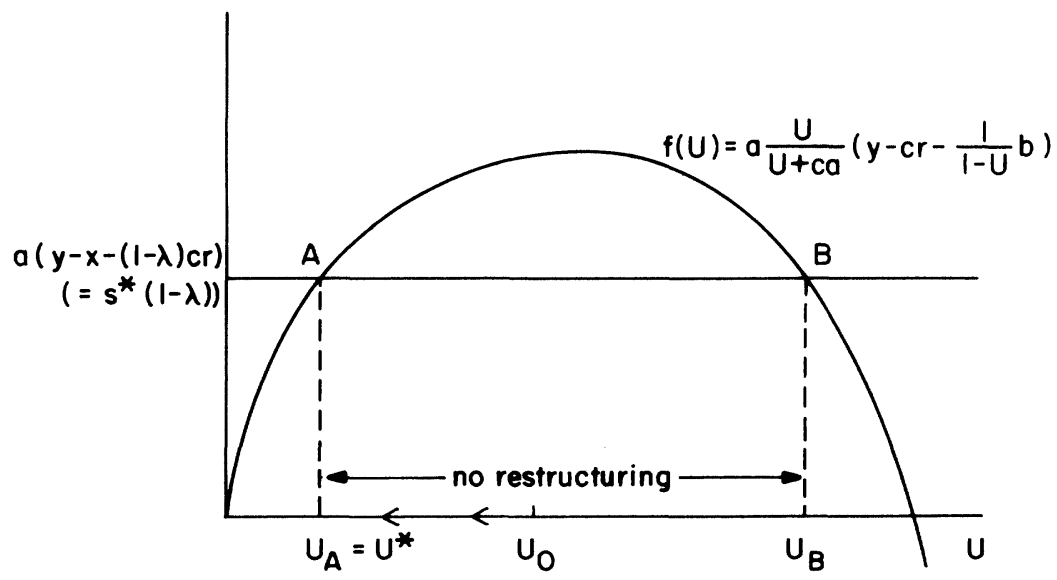


that case, even at zero unemployment, workers in state firms find it more attractive not to restructure. Thus, no restructuring takes place. The initial unemployment, $U_{0}$, is absorbed over time by private job creation, and the process then stops. The second case arises when the horizontal line is higher than maximum private job creation. At any unemployment rate, workers in state firms want to restructure. Neither case strikes us as capturing what has happened.

If we leave aside those two cases, the horizontal line intersects $f(U)$ twice, so that there are two equilibria, $U_{A}$ and $U_{B}$. As before, the higher unemployment equilibrium is unstable. Unless initial unemployment exceeds $U_{B}$, the economy converges to $U_{A}$.

If $U_{0}$ is less than $U_{A}$, unemployment jumps to $\dot{U}_{A}$. The probability of finding a private job and the private wage are both sufficiently high that workers in state firms prefer to restructure even if this may lead them to become unemployed. This adjustment is in the spirit of recent models, such as those sketched by Kehoe in his discussion of this paper, in which unemployment comes from the attractiveness for workers in low-productivity firms to search for high-productivity jobs. In our model, unemployment increases to the point where the probability of getting a private job when unemployed falls enough to make workers in state firms indifferent between restructuring or not restructuring. But one can think of other mechanisms, and some of them are presented by Kehoe.

The more empirically relevant case appears to us to be the other one, where $U_{0}$ is larger than $U_{A}$. In that case, high unemployment makes restructuring and privatization unattractive to workers in state firms. Thus, no restructuring takes place until private job creation has reduced unemployment to $U_{A}$. From then on, the economy transits at $U^{*}=U_{A}$ at speed $s^{*}=f\left(U_{A}\right)$.

\subsection{COMPARATIVE STATICS}

(1) Suppose that the government is able, say, through explicit wage controls, to decrease rent appropriation in state firms. We can capture this by assuming that workers in state firms now receive only $\alpha x-z$, where $\alpha$ is less than one. ${ }^{34}$

The horizontal line in Figure 3 shifts up, but the locus corresponding to $f(U)$ is unchanged. The effect is to increase both equilibrium unemployment and the speed of restructuring. Lower rent appropriation

34. This raises the possibility of using profits from state firms, which are positive if $\alpha<1$, to finance expenditures, such as unemployment benefits. We have not explored that channel in our model. 
makes restructuring and privatization relatively more attractive, leading to an increase in unemployment, until workers in state firms are again indifferent between restructuring or not restructuring. As equilibrium unemployment is on the upward-sloping part of $f(U)$, the net effect of higher unemployment is to increase private job creation and the speed of restructuring.

This is the effect, however, when the economy is already at $U^{*}$. If, e.g., initial unemployment $U_{0}$ is larger than $U^{*}$, then workers in state firms strictly prefer not to restructure. This is because high unemployment implies both a low private wage and a low exit rate from unemployment, two factors that make restructuring less attractive. In this case, (small) decreases in $\alpha$ make state workers worse off but still do not lead to restructuring. Thus, in the adjustment of the economy from $U_{0}$ to $U^{*}$, the effect of a decrease in $\alpha$ is to decrease the wage of state workers, but it has no effect on the evolution of unemployment.

(2) The distinction between the effects of a change in a parameter depending on whether the economy is or is not yet at $U^{*}$ is even more striking in the case of unemployment benefits.

Suppose that the economy is at $U^{*}$ and that unemployment benefits are increased. The $f(U)$ locus shifts downward, and the horizontal line is unaffected. Thus, higher unemployment benefits lead to higher unemployment but leave the speed of restructuring unaffected. Indeed, the effect of higher unemployment benefits is to decrease the welfare of the unemployed: The increase in benefits is more than offset by the decrease in employment prospects. ${ }^{35}$ This result is reminiscent of the Harris and Todaro (1970) model and indeed has the same causes: Making unemployment less unattractive leads to higher equilibrium unemployment, not necessarily higher welfare of the unemployed.

But the effects of benefits are quite different as long as unemployment is greater than $U^{*}$. In this case, marginal changes in benefits do not trigger restructuring. Higher benefits lead to higher wages and lower private job creation. Whether they lead to higher instantaneous utility for the unemployed is ambiguous: Higher unemployment benefits may be more than offset by the decrease in the exit rate.

\subsection{A NORMATIVE ANALYSIS}

Looking at the effects of policies on restructuring and unemployment raises the question of what the government should do. This in turn

35. To see that, note that the value of being employed in the state sector decreases with unemployment-because unemployment leads to higher taxes-and that the three values are linked by Equation (23), so that all three decrease. 
raises two other questions. What should the government maximize? And what tools does it have at its disposal?

We assume here that the government maximizes the present discounted value of output. Thus, we shall focus on efficiency and give no weight to income or unemployment distribution.

This leaves open the issue of what the government takes as given in solving its optimization problem. There is a sense in which the government can affect most of the parameters we have defined so far. For example, the strength of the effect of profit on private sector job creation, the parameter $a$, must depend in part on the organization of credit markets, which the government can improve. But allowing the government to choose $a$ freely clearly makes the optimization problem both trivial and unrealistic. Thus, we assume that the government takes the system of unemployment benefits, the wage determination process, and the equation for private job creation, as given. This implies that the government takes the function $d N / d t=f(U)$ as given and chooses the rate of restructuring. It can do this in our model, through changes in $\alpha$, or by imposing top-down privatization and restructuring, or by changing decision rules within firms. We shall not specify how at this point and just take the speed of restructuring as the control variable.

Finally, we assume, for simplicity, that $\lambda$ equals zero, so that the question becomes at what rate to close-rather than restructure-firms. This makes the algebra simpler, and little is lost in the process.

\section{Optimal unemployment and speed}

Under the assumptions above, the government maximizes

$\max \int_{0}^{\infty}\left(E x+N y-(1 / 2 a r) H^{2}\right) e^{-r t} d t$

subject to

$1=E+N+U ; \quad H=d N / d t=f(U)$.

The only term that deserves comment is the third term in the objective function. It captures the cost of creating private jobs and is quadratic in job creation; it is this cost function that implicitly underlies the relation between job creation and profit we postulated earlier.

Solving this maximization problem gives the following characterization of optimal unemployment, $U^{* *}$ :

$x=f^{\prime}\left(U^{* *}\right)\left[\left(y-\left(f\left(U^{* *}\right) / a\right)-x\right) / r\right]$. 
The interpretation of Equation (26) is straightforward. Closing one state job leads to a flow loss of $x$. The increase in unemployment leads to a marginal increase in private job creation of $f^{\prime}\left(U^{* *}\right)$. The additional flow output associated with a private job is equal to $y$, minus the marginal cost of job creation, $f\left(U^{* *}\right) / a r$. Therefore, the term in brackets gives the present value of replacing a state job by a private job.

The solution is for the government to achieve $U^{* *}$ and the associated speed of closing, $s^{* *}=f\left(U^{* *}\right)$. If $U^{* *}$ is less than initial unemployment $U^{0}$, then the optimal policy is not to start closing until unemployment has declined to $U^{* *}$.

\section{Now compare this optimal solution to equilibrium $U^{*}$.}

Starting from $V_{E}=V_{U}$, the restructuring condition when $\lambda=0$, and Equations (4), (5), and (17), gives:

$x-z=b+\left(f\left(U^{*}\right) / U^{*}\right)(w-x+z) / r$.

Using Equation (2) to eliminate $w$ gives an implicit characterization of equilibrium unemployment:

$x-z=b+\left(f\left(U^{*}\right) / U^{*}\right)\left[\left(y-\left(f\left(U^{*}\right) / a\right)-x\right) / r\right]$.

The interpretation of Equation (28) is also straightforward. Closing a state job costs the worker $x-z$. If she becomes unemployed, she gets unemployment benefit $b$ and faces a probability $f\left(U^{*}\right) / U^{*}$ of getting a private job. The term in brackets is the present value of the difference between private and the state wages.

All that remains to be done is to compare Equations (26) and (28). There are three differences; all three imply that equilibrium unemployment is larger than is optimal. The first is the presence of taxes, $z$, which reduce the relative attractiveness of state jobs compared with unemployment. The second is the presence of unemployment benefits, which have the same effect. The third is the presence of $f\left(U^{*}\right) / U^{*}$ rather than $f^{\prime}\left(U^{*}\right)$ in Equation (28). While the marginal effect of unemployment on private job creation, $f^{\prime}(U)$, is what is relevant for optimal unemployment, what matters to workers is the average effect $f(U) / U$. By concavity of $f(\cdot)$, the marginal effect is always smaller than the average effect; this factor leads again to too high unemployment. ${ }^{36}$

36. This effect plays an important role in Gavin (1993), where $f(U)$ reflects matching considerations. 
This normative analysis comes with the clear warning that it surely takes too much of the environment as given. Differential taxation of the private and state sector would, e.g., allow the government to modify $f(U)$, which we have taken as given. As it is, it suggests that equilibrium unemployment may be too high and that measures be taken to lower it. $^{37}$

\section{Returning to Poland and Central Europe}

\subsection{ON POLAND}

One of the two cases we characterized in the previous section was such that the initial level of unemployment exceeded equilibrium unemployment. As a result, there was no restructuring until private job creation had reduced unemployment to its equilibrium value.

We believe that this is an accurate, if rough, description of what has happened so far in Poland. The evidence suggests that the unemployment that has resulted from labor shedding far exceeds equilibrium unemployment: The exit rate from unemployment to employment is extremely low; private wages are lower than wages in state firms. It is not surprising that workers in most state firms are resisting restructuring and the associated risks of unemployment.

Our model makes a clear forecast. Restructuring will remain limited, until private job creation has sufficiently reduced the unemployment rate to make restructuring less unattractive. We also believe that forecast to be right. One qualification comes from the geographic heterogeneity, which is not in our model, but is very relevant in practice. In the major cities, unemployment is lower, and those labor markets are probably close to our description of equilibrium unemployment, with both restructuring and private job creation. The rest of the country corresponds more closely to our case where unemployment exceeds equilibrium unemployment. Unemployment is much higher, and there is much resistance to restructuring. This heterogeneity smooths, at the aggregate level, the sharp distinction present in our model between the cases where unemployment is at or above its equilibrium value.

When and how fast can one expect unemployment to decline? This depends mainly on two factors. The first is how much more labor state

37. When $\lambda$ is positive, the algebra is more intricate, but the same three effects are at work. One can then examine the implications of the alternative conditions for restructuring we discussed earlier. Using the condition that even those unemployed be as well off works in the opposite direction from the three effects listed earlier. It leads, other things equal, to too low a level of unemployment and to too slow a speed of restructuring, so that the net effect is, in this case, ambiguous. 
firms still need to shed in order to survive. (In our model, this labor shedding is instantaneous; but, as we showed earlier, this has been in fact a drawn-out process.) Our reading of the evidence suggests that this process may be nearly achieved. The second is the rate of private job creation. The numbers we presented in Table 2 are not reassuring: Net private job creation in private firms with more than five employees from 1992 to 1993 was only 0.1 million, compared with an unemployment pool of 2.8 million. While the message from this number is probably overly pessimistic, this suggests a slow decline in unemployment. This raises the issue of whether the increasing importance of long-term unemployment may change the relation between wage setting and unemployment as it has in Western Europe. This also suggests the importance of foreign direct investment, which is crucial to the creation and expansion of medium-size private firms.

Forecasts for productivity growth must also be modest. Labor shedding led to large gains in productivity in 1993, and more may come in 1994. But limited restructuring of state firms, at least until unemployment has significantly decreased, also implies that, despite the potential for further large gains in productivity, these will not be realized any time soon.

What should the government do ${ }^{38}$

The obvious implication of our model is that measures to accelerate private job creation dominate measures aimed at accelerating restructuring of state firms. Given the current unemployment rate, faster restructuring, even if it could be achieved-and we have argued this is unlikely to be the case-may lead to a level of unemployment that adversely affects transition.

The conclusion that restructuring not only will, but also can, wait clearly depends on our assumption that, after the initial labor shedding,

38. There is at least one important dimension of policy that our model is not designed to address, and to which we do not know the answer. It is the potential role of demand policies in maintaining or increasing employment in state firms. The general principle is that firms dominated by insiders are more likely to respond to increases in demand by increasing prices rather than by increasing output and employment; this is because workers who are already employed put little weight on additional employment for others. However, this is tempered at this point by the fact that, in many firms, the number of insiders still exceeds the feasible level of employment; in those firms, increases in demand are likely to lead to an increase in output, and an increase in employment.

The evidence from 1993 is encouraging here. The proximate cause of growth in 1993 was an increase in domestic consumption spending; this was accommodated by firms by an increase in output, a smaller decrease in employment than would have taken place otherwise, and a large increase in productivity growth. There was no pressure on inflation, which steadily decreased during the year. 
state firms can stay in a holding pattern for some time. This in fact depends on both market conditions (Will foreign competition intensify?) and on internal decisions (Will workers be willing, able to maintain the capital stock?). And this in turn raises the issue of whether the government can take measures to allow firms to stay in this holding pattern. Privatization through liquidation, for example, increases the horizon of workers by making them shareholders; but as we have seen, it may decrease rather than increase access to outside finance. Our model implies that capital privatization with employment commitments by firms may actually be desirable. ${ }^{39}$

\subsection{ON CENTRAL EUROPE}

The broad characteristics of transition in Poland, as we described them in Section 2, are shared by the other reforming Central European countries. But there are also some important differences, most notably in unemployment rates. One question is whether our model can not only help explain the common evolutions but also the differences across countries.

Basic numbers are presented in Tables 4 and 5 for Poland, Hungary, Slovakia, the Czech Republic, and Bulgaria. ${ }^{40}$

Table 4 presents the evolution of employment-total, state, private-, of unemployment, and of industrial production. The numbers for employment and unemployment are presented as changes since the beginning of reform, normalized by the initial labor force. ${ }^{41}$ The "ratio" variable gives the ratio of the change in unemployment to the negative of the change in employment. It provides a rough index of whether the decrease in employment has been reflected in a change in unemployment or in a change in labor force participation. ${ }^{42}$ Finally, to give a

39. Indeed, most capital privatizations in Poland have come with such-but rather limited-commitments.

40. Again, we cannot present historical evolutions. Our purpose is only to confront our model to the broad facts in those countries. This section is based in part on Blanchard et al. (1993), which is itself based on specific country studies under a World Bank project on labor markets in Central and Eastern Europe.

41. As our discussion of the Polish numbers earlier made clear, private and state employment numbers raise issues of both definition and measurement. A decline in state employment may reflect classification changes, privatization, or declines in employment in existing state firms. To the extent we could correct for classification changes, we have, and the numbers presented are mostly free of classification changes. Except for small-scale privatization of shops, the numbers are also not very much affected by privatization - which has been limited in scale in most countries, and the implications of which we exclude by construction for the Czech Republic.

42. It is only a rough index because a value of one may reflect either no change in participation, or a decrease in participation together with the entry of new cohorts in the labor force. 
Table 4 EMPLOYMENT, STATE AND PRIVATE, UNEMPLOYMENT, INDUSTRIAL PRODUCTION

\begin{tabular}{|c|c|c|c|c|c|c|}
\hline & \multicolumn{4}{|c|}{ Change } & \multirow[b]{2}{*}{ Ratio } & \multirow{2}{*}{$\begin{array}{l}\text { Industrial } \\
\text { Production }\end{array}$} \\
\hline & Total E & State E & Private E & $U$ & & \\
\hline Poland (a) & -12.6 & -20.3 & 7.7 & 14.2 & 1.12 & 71.5 \\
\hline Hungary (b) & -13.0 & -34.0 & 21.0 & 14.1 & 1.17 & 62.3 \\
\hline Slovakia (b) & -12.8 & -22.7 & 10.0 & 10.4 & 0.81 & 61.3 \\
\hline Czech Rep (c) & -8.8 & $(-16.1)$ & (10.7) & 2.5 & 0.28 & 59.6 \\
\hline Bulgaria (b) & -24.0 & -34.7 & 10.7 & 14.0 & 0.58 & 47.0 \\
\hline
\end{tabular}

All changes expressed as ratios to the initial labor force. "Ratio" is the ratio of the change in unemployment to the negative of the change in employment. The industrial production index is equal to 100 in 1989.

Source: Blanchard et al. (1993). (a) 1992 over 1989; state employment includes cooperatives. (b) 1992 over 1990. (c) Change in total employment: 1992 over 1990. Changes in state and private employment: 1991 over 1990. Large-scale privatization leads in 1992 to a further shift of $22 \%$ of the labor force from state to private employment.

\section{Table 5 PRIVATE / STATE WAGE RATIOS AND EXIT RATES} FROM UNEMPLOYMENT

\begin{tabular}{lcc}
\hline & Wage ratio & Exit rate $(\%)$ \\
\hline Poland & 0.86 & 2.3 \\
Hungary & 0.93 & 3.0 \\
CSFR & 1.08 & 4.8 \\
Slovakia & & 18.0 \\
Czech Rep & 1.16 & 1.1 \\
Bulgaria & 1.16 \\
\hline
\end{tabular}

Source: Blanchard et al. (1993). Wage ratio: ratio of average private wage to average state wage, for 1993 . Exit rate: monthly exit rate from unemployment to employment, 1992 average.

sense of the size of the shock that has affected the industrial sector, the last column gives the industrial production index.

Table 5 gives numbers for two of the variables that play an important role in our model, the wage in the private sector relative to the state sector, and the exit rate from unemployment to employment. ${ }^{43}$

These tables-and the larger body of evidence-suggest a three-way classification: The experience of Hungary and Slovakia appear broadly similar to that of Poland. In all three countries, employment is down by

43. Issues of measurement also apply to the wage ratio, which does not take into account fringe benefits (which are higher in the state sector), and does not adjust for composition effects. The study by Commander et al. (1993) on Hungary, which controls for worker and industry characteristics, finds private and state hourly wages to be roughly equal. 
about $12 \%$ from its pre-reform level; this reflects a much larger decrease in state employment, only partly offset by an increase in private employment. ${ }^{44}$ Unemployment has increased roughly one for one with the decrease in employment. In all three countries, the exit rate from unemployment to employment is very low, from $2.3 \%$ in Poland to $4.8 \%$ in Slovakia.

Other aspects appear to fit as well. After a rapid initial increase, the rate of private job creation is low: Measured private employment in Hungary and Slovakia were nearly the same in 1992 as in $1991 .{ }^{45}$ Privatization is nearly at a standstill. The prognosis is broadly similar to that of Poland. The current level of unemployment appears to far exceed equilibrium unemployment. Labor productivity in industry is roughly back to its pre-reform level, so that there may not be much more labor shedding needed for the remaining firms to survive, and unemployment may not increase further. From then on, private job creation is likely to slowly decrease unemployment. Restructuring is likely to remain limited for some time to come.

Looking at unemployment, the next country in Table 4, the Czech Republic, appears to be doing much better: The unemployment rate is below $3 \%$. The exit rate from unemployment to employment is equal to $18 \%$ per month, giving a very different view of the unemployment pool. But the other numbers in Table 4 show that the difference is in fact less than first appears. The decrease in employment is only marginally smaller than in the countries we just looked at. The numbers for changes in state employment are available up to 1991 only; from what we know about the decline in employment in industry in 1992, numbers for the decline in state employment for 1990 to 1992 surely exceed $20 \%$ (excluding the effects of large-scale privatization). The evidence from the decline in industrial production does not suggest that the Czech Republic has been hit less hard than the others by relative price changes and the collapse of trade. The major difference between the Czech Republic and the previous countries is in the ratio of the change in unemployment to the negative of the change in employment; two factors appear to be at work: tough unemployment eligibility requirements, which have led workers to drop out of the labor force altogether, as well as unrecorded private activities. ${ }^{46}$ Were the ratio of changes in unemployment to changes in employment equal, say, to the

44. The smaller increase in private employment in Poland reflects the fact that the private sector was larger to start with. Poland is the country with the largest share of private employment.

45. See Table 1 in Blanchard et al. (1993).

46. There is solid evidence of the first. There is, as far as we know, only anecdotal evidence of the second. 
value for Poland, unemployment in the Czech Republic would be equal to $10 \%$. Thus, while the Czech Republic is doing better, the difference is smaller than suggested by the unemployment numbers.

There is another important difference between the Czech Republic and the other countries in Table 4. Large-scale privatization is being rapidly implemented and will imply a transfer of control from the insiders to outside investors. ${ }^{47}$ Thus, while restructuring has been limited, it is likely to take place earlier and at a higher rate than elsewhere. This suggests that unemployment may well increase in the future, as an implication of a faster speed of restructuring.

The last country in Table 4 is Bulgaria. Its performance has been distinctly worse than that of the other countries. The decline in state sector employment has been larger, and private sector growth has been limited. Unemployment stood in 1992 at 14\%, but even this high number hid a drop in participation. Had the ratio of changes in unemployment to employment been the same as in Poland, say, unemployment would have stood at $27 \%$. (Note that these are numbers for 1992. The unemployment rate has increased by another $10 \%$ since then.) The exit rate from unemployment to employment was a very low $1.1 \%$. The effects of the sharp decrease in activity back on the transition are clear. Government revenues, which stood at $58 \%$ of GDP in 1988 were down to $34.0 \%$ in 1992; capital expenditures were down from $8.5 \%$ to $2.6 \%$. Privatization is still to come. In terms of our model, this suggests an increase in the initial unemployment so far above the equilibrium rate (close to $U_{B}$ in Figure 3 ) that it threatens even the eventual success of the transition; high unemployment is leading to low private job creation. It will decline slowly at best.

\section{Conclusions and Extensions}

Our purpose in this paper was to develop a model of transition for Central Europe. Our model is based on two main assumptions. The first is that, after a rapid initial adjustment, private job creation will take time and that it is affected by unemployment: At low levels of unemployment, higher unemployment helps job creation; at higher levels, higher unemployment hinders and may even destroy job creation. The second is that restructuring in the state sector requires the support of

47. Why insiders have agreed to such a privatization program is, in view of our discussion earlier, a very relevant question. Frydman and Rapaczynski (1993) offer an interesting answer, that managers assumed that voucher privatization would lead to decentralized ownership and leave them in control. The emergence investment funds, which bought vouchers from individuals, have proved them wrong. Most firms will have a few large shareholders. 
the insiders, so that the speed of restructuring depends on labor market conditions as well: In particular, high unemployment hinders restructuring.

Our model delivers an equilibrium rate of unemployment and speed of restructuring, which are such that the flow into unemployment from restructuring is just absorbed by the rate of private job creation. It also implies that the initial adjustment can lead to an initial unemployment rate that exceeds the equilibrium rate. In this case, restructuring does not take place until job creation has reduced unemployment to low levels. If unemployment is high, and private creation slow, this adjustment will take a while. We argue that this configuration fits well the experience of most Central European countries.

Our model has a number of policy implications. Among them is that, in the initial phase of adjustment, priority should be given to private job creation. Trying to increase the speed of restructuring of state firms may not be feasible-running into opposition from workers in state firms-and may not be desirable anyway: Even if restructuring increases output, its indirect effects through unemployment on private job creation may make it undesirable if unemployment is already high.

In laying out our assumptions, we explained how we thought they captured the important aspects of transition. In ending this paper, we want to return to the various choices we made, some of the reservations we have, and some of the extensions we want to explore in the future.

(1) We have simply assumed that state firms faced a hard budget constraint. For Poland, as well as for the countries we looked at in this section, it is indeed the case that the constraint has steadily hardened. But this is not true, as is well known, of Russia or, to a lesser degree, of Romania. And it cannot be taken for granted that it will remain true even in the countries we have looked at. Bulgaria comes to mind here. A better model would endogenize the softness of the budget constraint and its transfer implications. We believe that it would lead to a better discussion than in our model of what may go wrong, if and when, in particular, unemployment becomes very high.

(2) We have maintained the assumption that even absent restructuring, state firms can, after some initial labor shedding, remain in a holding pattern. One may instead argue that, absent restructuring, state firms do not go into a holding pattern, but rather are likely to keep declining. If this is the case, our conclusions that restructuring can wait may be overturned. Both too fast and too slow a speed of restructuring can derail the transition. ${ }^{48}$ 
(3) We have ignored heterogeneity across state firms in both shocks and restructuring prospects. This leads in our model to a sharp distinction between two phases, the cases where unemployment is greater or equal to its equilibrium value. This distinction is too sharp. Heterogeneity would smooth those phases. More importantly, it would allow for a better discussion of the role of subsidies and tariffs in the transition, along the lines of Flemming (1993).

(4) We have focused on the role of workers in restructuring and formalized the restructuring decision in a simple way. But the reality is more complex, with games between workers, and between management and workers, and where the outcome depends both on the institutional environment and the characteristics of firms. We explored some of these issues in Aghion et al. (1993) in a partial equilibrium model. Bringing them in a general equilibrium framework, and thinking about the role of the government in that context, strikes us as promising.

(5) A related issue is the relation between restructuring and privatization. As we showed in our description of Poland earlier, our assumption that restructuring and privatization happen simultaneously is not correct: Privatization does not necessarily lead to restructuring, and whether it does depends in part on the form of privatization. A more explicit treatment of the relation between privatization and restructuring may help assess if, e.g., increasing the speed of privatization by making it easier for insiders to acquire their firms is likely to help or hinder the process of transition.

(6) Finally, we have treated private job creation as a black box. Looking within the black box, and in particular looking at the role of financial intermediation, and within that, the role of banking reform, also strikes us as important.

\section{REFERENCES}

Aghion, P., and O. Blanchard. (1994). Notes on minimum and maximum speeds of transition, mimeo MIT.

and R. Burgess. (1993). The behavior of state firms in Eastern Europe pre-privatization, EBRD WP 12, European Economic Review, in press.

Atkeson, A., and P. Kehoe (1992). Industry evolution during transition and the role of informational capital. Mimeo.

Berg, A. (1993). Measurement and mismeasurement of economic activity during transition to the market. Eastern Europe in Transition: from recession to growth?, World Bank Discussion Papers 196:39-63.

and O. Blanchard. (1994). Stabilization and transition in Poland; 1990-1991. In The transition in Eastern Europe, vol. 1. O. Blanchard, K. Froot, and J. Sachs (eds.). Chicago: NBER and University of Chicago Press, pp. 51-92. 
Blanchard, O., S. Commander, and F. Coricelli. (1993). Unemployment and restructuring in Eastern Europe. Mimeo, World Bank.

Boeri, T., A. Reutersward, and S. Scarpetta. (1993). Unemployment benefit systems and active labour market policies in Central and Eastern Europe: An overview. Mimeo OECD-CCET, October.

Boyko, M., A. Shleifer, and R. Vishny. (1993). Privatizating Russia. Brookings Papers on Economic Activity 2:139-180.

Caballero, R., and M. Hammour. (1993). On the timing and efficiency of creative destruction. Mimeo, December, MIT.

Calvo, G., and F. Coricelli. (1993). Output collapse in Eastern Europe: The role of credit, in Eastern Europe in transition: From recession to growth? World Bank Discussion Papers 196:92-105.

Carlin, W., J. Van Reenen, and T. Wolfe. (1994). Enterprise restructuring in the transition; an analytical survey of the case study evidence from Central and Eastern Europe. Mimeo, EBRD.

Chadha, B., F. Coricelli, and K. Krajnyak. (1992). Economic restructuring, unemployment and growth in a transition economy. Mimeo, IMF.

Commander, S., J. Kollo, C. Ugaz, and B. Vilagi. (1993). Hungary, World Bank Conference on "Unemployment, restructuring and the labor market in East Europe and Russia."

Dabrowski, J., M. Federowicz, T. Kaminski, and J. Szomburg. (1993). Privatization of Polish state-owned enterprises: progress, barriers, initial effects. Gdansk Institute for Market Economics, 33.

DAI. (1993). Financial sector reform in Central and Eastern Europe. Report for the US Agency for International Development.

Estrin, S., A. Gelb, and I. Singh. (1993). Restructuring, viability and privatization: a comparative study of enterprise adjustment in transition. Mimeo, World Bank.

Fan, Q., and M. Schaffer. (1993). Government financial transfers and enterprise adjustments in Russia, with comparisons to Central and Eastern Europe. CEP WP 394, June.

Flemming, J. (1993). Relative price shocks and unemployment: arguments for temporarily reduced payroll taxes or protection. Mimeo, EBRD.

Frydman, R., and A. Rapaczynski. (1993). Privatization in Eastern Europe: Is the state withering away. CVStarr Newsletter 11. , and J. Earle. (1993). The privatization process in Central Europe. New York: Central European University Press.

Gavin, M. (1993). Unemployment and the economics of gradualist policy reform. Mimeo, Columbia University, January.

Gomulka, S. (1993a). The financial situation of Polish enterprises 1992-93 and its impact on monetary and fiscal policies, Working paper 6, CASE, Warsaw, December.

(1993b). On the design of economic policy: The challenge of Eastern Europe. In Economic growth in the world economy, Horst Siebert (ed.). Tubingen: J. C. B. Mohr.

Gora, M. (1994). Labour market flows in economies in transition; the case of Poland. Mimeo, Warsaw School of Economics.

Harris, J., and M. Todaro. (1970). Migration, unemployment and development: A two-sector analysis. American Economic Review 60:126-142. 
Lipton, D., and A. de Combrugghe. (1994). The government budget and the economic transformation of Poland. In Transition in Eastern Europe, vol. 2, O. Blanchard, K. Froot, and J. Sachs (eds.). Chicago: University of Chicago Press.

, and J. Sachs. (1990) Creating a market economy in Eastern Europe: The case of Poland. Brookings Papers on Economic Activity 1:75-133.

Pinto, B., M. Belka, and S. Krajewski. (1993). Transforming state enterprises in Poland: Evidence on adjustment by manufacturing firms. Brookings Papers on Economic Activity 1.

Rostowski, J. (1993). The implications of rapid private sector growth in Poland. Discussion paper 159, Centre for Economic Performance, London.

Sachs, J. (1993). Poland's jump to the market economy. Cambridge, MA: The MIT Press.

Schaffer, M. (1992). The Polish state-owned enterprise sector and the recession in 1990. Comparative Economic Studies 34.

\section{Comment}

PATRICK J. KEHOE

University of Pennsylvania and Federal Reserve Bank of Minneapolis

I enjoyed reading the paper. It is well written and well worth reading. It discusses some interesting data and raises some issues that economists working on transition need to struggle with. Since Andy Atkeson and I have been struggling with many of these same issues but don't often cross paths with Olivier, I welcome the chance to discuss these with him.

Aghion and Blanchard present evidence from Poland that from the beginning of 1990 through the end of 1991, real GDP dropped 20\%, industrial production dropped more than $30 \%$, and unemployment rose to about $12 \%$. They build a simple qualitative model that captures some of these features of the aggregate data as well as some micro details, including ownership structure within firms and policies for unemployment benefits.

In this comment I do four things. First, I discuss some details of the data. Second, I discuss four possible explanations of the data. Third, I focus on the explanation of Aghion and Blanchard by building a little model that captures most of the insights of their story. Fourth, I end with some questions about the specifics of their model.

\section{Data Issues}

Consider the macro data. When I think about different potential stories to tell about the reform, I find it crucial to have data on labor productiv- 